\title{
Optimization, Purification, and Starch Stain Wash Application of Two New $\alpha$-Amylases Extracted from Leaves and Stems of Pergularia tomentosa
}

\author{
Imen Lahmar, ${ }^{1}$ Hanen El Abed, ${ }^{2}$ Bassem Khemakhem, ${ }^{2}$ Hafedh Belghith, ${ }^{3}$ \\ Ferjani Ben Abdallah, ${ }^{1}$ and Karima Belghith ${ }^{2}$ \\ ${ }^{1}$ Laboratory of Plant Biodiversity and Dynamics of Ecosystems in Arid Environment, Faculty of Sciences, University of Sfax, \\ Sfax, Tunisia \\ ${ }^{2}$ Laboratory of Plant Biotechnology Applied to Crop Improvement, Faculty of Sciences, University of Sfax, Sfax, Tunisia \\ ${ }^{3}$ Laboratory of Molecular Biotechnology of Eukaryotes, Center of Biotechnology, Sfax, Tunisia \\ Correspondence should be addressed to Imen Lahmar; imen.lahmer@yahoo.fr
}

Received 24 August 2017; Accepted 27 November 2017; Published 17 December 2017

Academic Editor: Pierluigi Di Ciccio

Copyright (C) 2017 Imen Lahmar et al. This is an open access article distributed under the Creative Commons Attribution License, which permits unrestricted use, distribution, and reproduction in any medium, provided the original work is properly cited.

\begin{abstract}
A continuous research is attempted to fulfil the highest industrial demands of natural amylases presenting special properties. New $\alpha$-amylases extracted from stems and leaves of Pergularia tomentosa, which is widespread and growing spontaneously in Tunisia, were studied by the means of their activities optimization and purification. Some similarities were recorded for the two identified enzymes: (i) the highest amylase activity showed a promoted thermal stability at $50^{\circ} \mathrm{C}$; (ii) the starch substrate at $1 \%$ enhanced the enzyme activity; (iii) the two $\alpha$-amylases seem to be calcium-independent; (iv) $\mathrm{Zn}^{2+}, \mathrm{Cu}^{2+}$, and $\mathrm{Ag}^{2+}$ were considered as important inhibitors of the enzyme activity. Following the increased gradient of elution on Mono Q-Sepharose column, an increase in the specific activity of 11.82-fold and 10.92-fold was recorded, respectively, for leaves and stems with the presence of different peaks on the purification profiles. Pergularia amylases activities were stable and compatible with the tested commercial detergents. The combination of plant amylase and detergent allowed us to enhance the wash performance with an increase of 35.24 and $42.56 \%$, respectively, for stems and leaves amylases. Characterized amylases were reported to have a promoted potential for their implication notably in detergent industry as well as biotechnological sector.
\end{abstract}

\section{Introduction}

Maltogenic amylases are widely distributed in microorganisms, plants, and higher organisms and constitute a subfamily of amylolytic enzymes [1,2]. Through their transglycosylation activity, they were responsible for the solubility increase, the oxidative stability, the sweetness, and the carcinogenicity decrease [3, 4]. Belonging to this enzyme family, $\alpha$-amylases (1,4-a-D-glucan glucanohydrolase) catalyze the hydrolysis of $\alpha-1,4$ glycosidic linkage in starch and related polysaccharides. They represent approximately $25 \%$ of industrial enzymes in the global market [5]. Hence, they have an industrial importance which is intensified by their thermal resistance and adaptation to special processes as brewing and liquefaction process [6], paper and textile sectors [7], and heavyduty and dishwashing detergents [8]. Currently, $\alpha$-amylases were implied also in chemistry, clinical, pharmaceutical, or analytical process [9].

From the worldwide enzyme manufacturing, $\alpha$-amylases are included in about $30 \%$ of the global detergent industries and in $90 \%$ of the solid-liquid laundry $[10,11]$. Despite the continuous need of the discovery of new enzymes suitable for new detergent formulations, microbial amylases still have the crucial interest [12-15]. A few researches focused on plants amylases quite useful for cleaning purposes, such as the case of immobilized $\alpha$-amylase soybean onto chitosan enhancing 
the removal of starch stains [16]. With the ignorance of their local endogenous applications [17], the need to characterize plant amylases by means of their stability, specificity, optimal activity range, and metal dependence still remains.

The fact that $\alpha$-amylases are commonly extracted and purified from different plant organs, such as tubers [18], leaves [19], seeds [20, 21], and stems [22], encourage us to focus on the plant source and mainly wild plants which are not studied in the literature and which may present interesting specific and unique properties. While plants have been considered as a source of abundant enzymes which were well searched in food sectors [23], less attention has been paid to species which can be included in industrial starch processing like Triticum aestivum, Manihot esculenta, and Zea mays [24].

Asclepiadaceae family was characterized by the richness of several species in different enzymes. Asclepias fruticosa contains asclepain in its latex [25] and calotropain was discovered in Calotropis procera [26]. A cysteine protease hydrolysing the fibrinogen was found in Pergularia extensa and Cynanchum puciflorum [27]. Belonging to this family, Pergularia tomentosa has gained a recent scientific importance due to its proteinases, rennin, polyphenol oxidase, tyrosinase, $\beta$-amylase, lipase, $\mathrm{L}$-asparaginase, and lipoxygenase widespread in the latex compared to the crude extract of the whole plant [28-30]. According to the literature, this rangeland species of Pergularia contains several secondary metabolites, antioxidative bioactive molecules, and potent antifungal compounds against Fusarium oxysporum f.sp. lycopersici $[31,32]$. It was used as a remedy in traditional medicine in case of tuberculosis, skin diseases, and constipation [33]. It presented anti-inflammatory [34], antidermatophytic [35], molluscicidal [36], and antimicrobial activities $[37,38]$ and it was known as anticancer agent [39] and insect repellent [40].

In view of the above, the present study reports the purification of $\alpha$-amylases extracted from leaves and stems of the wild medicinal plant, Pergularia tomentosa. Several conditions were also optimized such as $\mathrm{pH}$, temperature, and substrate concentration. Additional ions in the reaction medium were classified as activators or inhibitors to achieve high and better enzyme activity.

We also intended to evaluate the stain remover potential of extracted enzymes view of the high detergent industry requisition of amylases using low-cost raw materials. The main purpose of the enzyme application raised in this study is to investigate the cleaning efficiency of plant amylase combined to laundry detergent and its distinctive compatibility as a highly efficient new additive.

\section{Materials and Methods}

2.1. Plant Material. Pergularia tomentosa L. was identified and collected from the surrounding of Bir Ben Ayed (south of Sfax, Tunisia) [31]. Stems and leaves were rinsed carefully with distilled water to be purified from soil and air environmental impurities. Plants were deposited onto filter paper until relative drying after the rinsing step. Each organ was ground separately in the minimum of distilled water. The mixture was centrifuged at $5000 \times \mathrm{g}$ for $30 \mathrm{~min}$ and the obtained supernatant was filtered through the filter paper $(150 \mathrm{~nm}, 5 \mathrm{~B}$, Advantec Tokyo, Japan) to obtain a clear crude extract.

2.2. Precipitation of $\alpha$-Amylase and Enzyme Assay. Protein precipitation with ammonium sulphate at $80 \%$ was carried out with a continuous gentle stirring in ice bath and was stored later overnight at $4^{\circ} \mathrm{C}$ [41]. The solution was centrifuged at $12,000 \times \mathrm{g}$ for $30 \mathrm{~min}$ and at $4^{\circ} \mathrm{C}$. The obtained precipitate was dissolved in distilled water and dialyzed against the same solvent for $24 \mathrm{~h}$ at $4^{\circ} \mathrm{C}$ and by changing the solvent thrice. Dialysis was carried out using cellulose tubing (molecular weight cut-off $13,000 \mathrm{kDa}$, Himedia LA393$10 \mathrm{MT})$.

The protein content was determined by the Bradford method [42] referring to bovine serum albumin. $\alpha$ Amylase assay was carried out following the DNS (2-OH-3.5dinitrobenzoic acid) method of Miller [43]. Optical density was measured at $550 \mathrm{~nm}$ against substrate and enzyme blank. One unit of amylase was defined as the enzyme amount which releases $1 \mu$ mole of glucose per minute.

2.3. Effect of $\mathrm{pH}$ and Temperature. $\mathrm{pH}$ optimum was determined by incubating the amylase-substrate reaction for $10 \mathrm{~min}$ at different $\mathrm{pH}$ ranging from 4.0 to 10.0 . Temperature optimization of amylase was determined by carrying the reaction mixture for $10 \mathrm{~min}\left(40-60^{\circ} \mathrm{C}\right)$ and keeping a constant $\mathrm{pH}$ [44]. $\mathrm{pH}$ stability was studied by preincubating $0.5 \mathrm{~mL}$ of enzyme with $0.1 \mathrm{M}$ buffer at different $\mathrm{pH}$ values for $3 \mathrm{~h}$ at $4^{\circ} \mathrm{C}[45]$. The thermal stability of $\alpha$-amylase was tested by incubating the enzyme for $3 \mathrm{~h}$ at the determined $\mathrm{pH}$ optimum and at 50 and $60^{\circ} \mathrm{C}$. Samples were withdrawn every $15 \mathrm{~min}$ and residual activity was determined.

2.4. Effect of Substrate Concentration and Metal Ions. Pergularia tomentosa $\alpha$-amylases activity was determined at several starch concentrations at the range of 1 to $2.5 \%$ and dissolved in $0.1 \mathrm{M}$ buffer at the $\mathrm{pH}$ optimum. The maximum activity was taken as $100 \%$ and relative activity was plotted against different concentration values.

$\mathrm{Ca}^{2+}, \mathrm{Mg}^{2+}, \mathrm{Cu}^{2+}, \mathrm{Fe}^{2+}, \mathrm{Mn}^{2+}, \mathrm{Zn}^{2+}, \mathrm{Fe}^{3+}$, and $\mathrm{Co}^{2+}$ at 1 and $5 \mathrm{mM}$ were supplemented in the reaction medium of enzyme extract and starch solution and incubated for $30 \mathrm{~min}$ at $\mathrm{pH}$ and temperature optimum of each plant organ. The enzyme activity without addition of any ions (inhibitor or activator) was considered as $100 \%$.

2.5. Purification of $\alpha$-Amylase. The dialyzed fraction was heated at $60^{\circ} \mathrm{C}$ in water bath for $15 \mathrm{~min}$ and the denatured protein precipitate was removed by centrifugation, while the supernatant was checked for activity. Obtained active fraction was loaded onto a Mono Q-Sepharose column $(2.1 \times 24 \mathrm{~cm})$ preequilibrated with $6.5 \mathrm{mM}$ sodium phosphate buffer $(\mathrm{pH}$ $5.0)$ at $4^{\circ} \mathrm{C}$. The same buffer was used to wash the column. Bounded proteins were eluted by a linear gradient of $\mathrm{NaCl}(0$ $1 \mathrm{M}$ ) in the same buffer at a flow rate of $5 \mathrm{~mL} \mathrm{~min}^{-1}$. Protein content was determined at $280 \mathrm{~nm}$ according to the method 
of Bradford [42]. Amylase activity of the recovered fractions was determined following the DNS method [43].

2.6. Compatibility of Stems and Leaves $\alpha$-Amylases with Commercial Detergents. The compatibility of stems and leaves $\alpha$-amylases with commercial available laundry detergents, Persil, Tide, and Savex, was determined. Detergent solutions with a concentration of $7 \mathrm{mg} / \mathrm{mL}$ were boiled for $90 \mathrm{~min}$ to inactivate any enzyme activity included on their formulation. Cooled solutions were mixed separately with each amylase $(1: 1)$ and incubated at $50^{\circ} \mathrm{C}$ for 1 hour. The residual activity was calculated in comparison with the control (instead of the detergent solution).

2.7. Efficiency of Stems and Leaves $\alpha$-Amylases in Starch Stain Wash. Wash efficiency of starch stains was studied in the presence of Savex detergent and the two Pergularia $\alpha$ amylases [46]. White cotton cloth pieces stained with starch solution $(0.5 \%)$ were placed at $80^{\circ} \mathrm{C}$ for $30 \mathrm{~min}$ to assume the firm binding of stains to the material support. Washing performance was tested by varying the cleaner, as water, water + detergent, water + enzyme, water + detergent $(7 \mathrm{mg} / \mathrm{mL})$ + enzyme. Stained cotton cloth piece was incubated in the presence of the corresponding cleaner mixture on a shaker platform $(100 \mathrm{rpm})$ for $30 \mathrm{~min}$ at $50^{\circ} \mathrm{C}$. Obtained solution was collected for each mixture to measure the concentration of reducing sugars released from starch [43]. The blank consists in distilled water instead of wash liquid. The same assay procedure was followed for stems and leaves $\alpha$-amylases.

The efficiency of starch removal by the washing process was expressed as the following equation [47]:

$$
\text { Efficiency } \%=\frac{100 * A * 0.9}{B},
$$

where $A$ is the amount of glucose released $(\mathrm{g} / \mathrm{mL})$ during the wash procedure and $B$ is the amount of starch $(\mu \mathrm{g} / \mathrm{mL})$ used for staining the cotton cloth piece.

2.8. Statistical Analysis. Data were expressed as mean \pm standard deviation and comparisons were made with appropriate controls using Student's $t$-test. Confidence limits were set at $p<0.05$ for all values analyzed in triplicate.

\section{Results and Discussion}

3.1. Optimization and Characterization of $\alpha$-Amylases. The highest amylase activity of Pergularia tomentosa was exhibited at $\mathrm{pH} 5.5$ in case of leaves and at $\mathrm{pH} 6.0$ for the stems (Figure 1). Between $\mathrm{pH} 4.0$ and 6.5, the relative activity of stems amylase retained more than $60 \%$ of the maximal activity. However, in case of leaves, $60 \%$ of retained activity was observed at the range of $\mathrm{pH}$ 5.0-7.0. Beyond $\mathrm{pH}$ 8.0, the amylase activity loss was $68 \%$ of the initial relative activity. It may be due to the $\mathrm{pH}$ effect on the ionization of the group of lateral chains maintaining the enzyme structure and its influence on the active site activities. The $\mathrm{pH}$ optimum of amylase extracted from germinated seeds of Glycine max is similar to our studied stems [48], while leaves $\alpha$-amylase

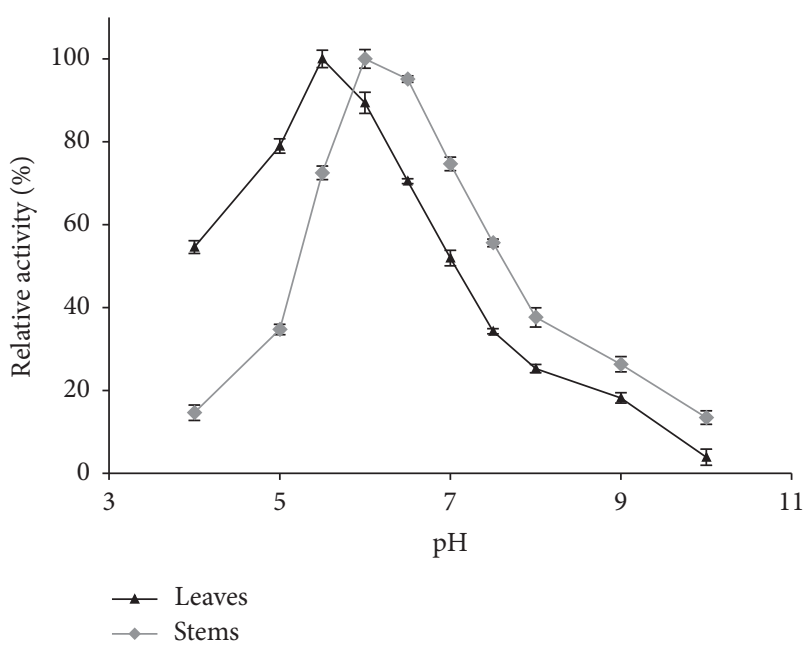

FIGURE 1: Effect of $\mathrm{pH}$ on the activity of $\alpha$-amylases extracted from leaves and stems.

presented the same $\mathrm{pH}$ of Carthamus tinctorius amylase isolated from seeds [49].

Enzymes were incubated for $3 \mathrm{~h}$ in several buffers; more than $80 \%$ of leaves enzyme activity was retained between $\mathrm{pH}$ 5 and 8 , suggesting that it was very stable despite the high $\mathrm{pH}$ (Figure 2(a)). Compared to the process of leaves amylase, a considerable loss of activity was observed in acidic $\mathrm{pH}$ for stems enzyme (Figure 2(b)). The latest amylase was kept stable in the $\mathrm{pH}$ range 6-8 and retained approximately $60 \%$ of the initial activity after $180 \mathrm{~min}$ of incubation.

The curves of the amylase activities as a function of the temperature looked bell-shaped with an optimum at $50^{\circ} \mathrm{C}$ (Figure 3). Both of stems and leaves curves coincide at the interval of 47 and $52^{\circ} \mathrm{C}$. The increase of the temperature was relatively going with the $\alpha$-amylases activity increase, between 40 and $50^{\circ} \mathrm{C}$, as assayed at the $\mathrm{pH}$ optimum of each plant organ. Beyond the peak of $50^{\circ} \mathrm{C}$, the activity began to decline roughly until the temperature changed from 53 to $60^{\circ} \mathrm{C}$. Above $60^{\circ} \mathrm{C}$, enzymes still retained more than $60 \%$ of their initial activities. The temperature optimum varies among species; furthermore, optimal activity of our identified $\alpha$-amylases was slightly lower than Vigna radiata and Pinus koraiensis $\left(65^{\circ} \mathrm{C}\right)[50]$.

Thermophilic amylases are mostly searched for starch industries applications [51]. Our leaves amylases are stable at $50^{\circ} \mathrm{C}$ beyond $150 \mathrm{~min}$ and lose just $2 \%$ of their initial activity after $90 \mathrm{~min}$ of incubation (Figure $4(\mathrm{a})$ ). At $60^{\circ} \mathrm{C}$ and after $90 \mathrm{~min}$ of enzyme incubation, $38 \%$ of the initial activity was lost. In the case of stems, $55 \%$ of the initial activity remained at $60^{\circ} \mathrm{C}$ beyond $100 \mathrm{~min}$ (Figure 4(b)). The thermal stability of the studied enzymes greatly exceeds the results of Haifeng where the enzyme of Aureobasidium pullulans was completely denatured at $60^{\circ} \mathrm{C}$ after $50 \mathrm{~min}$ [52]. This higher percent of the activity retention and thermal stability further encourages the implication of Pergularia tomentosa $\mathrm{L}$. in various practical sectors. The observed differences towards the process behavior may be due to the particular genetic heritage of each species [53]. And this thermal stability can 


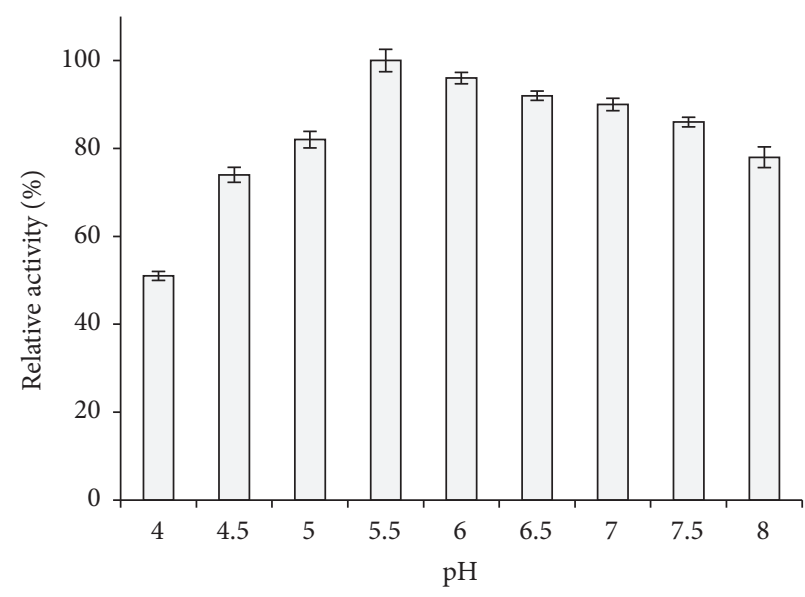

(a)

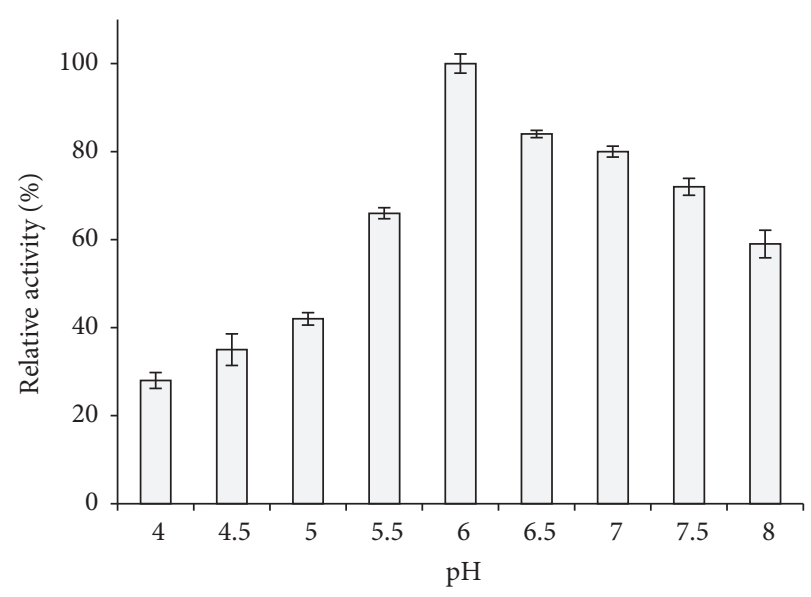

(b)

FIgURE 2: $\mathrm{pH}$ stability of $\alpha$-amylases extracted from leaves (a) and stems (b).

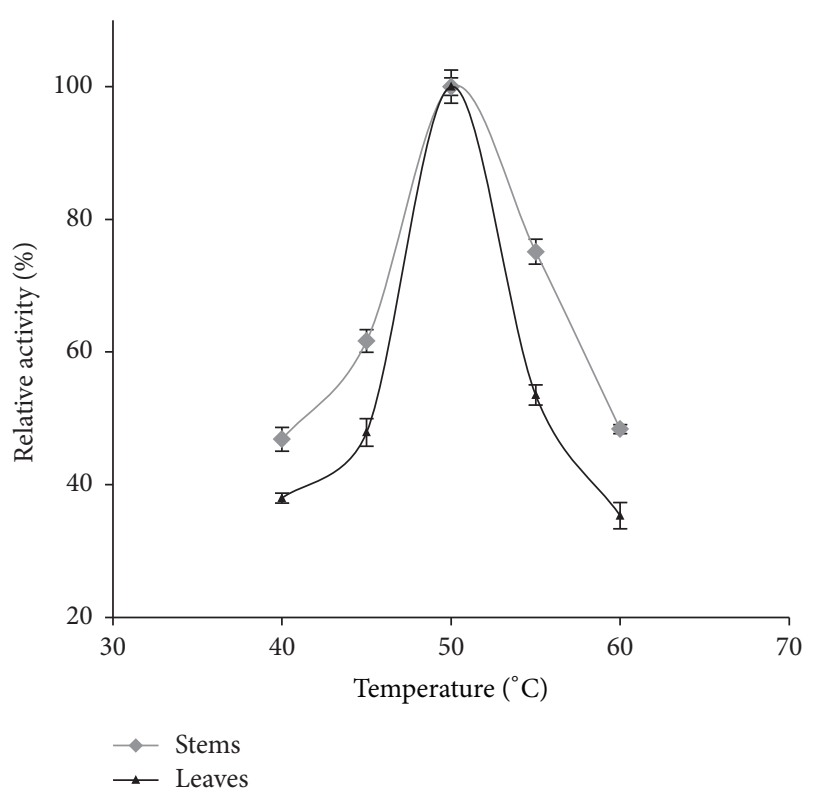

FIGURE 3: Effect of temperature on the activity of $\alpha$-amylases extracted from leaves and stems.

be attributed to the presence of some secondary and tertiary binding of the enzymatic proteins enhancing the enzyme structure consolidation and its resistance to the thermal treatment [54].

The effect of substrate concentration was maximal at $1.0 \%$ of starch solution in case of leaves and stems (Figure 5). This concentration was also frequently used for amylase assay in previous researches $[55,56]$. However, the substrate concentration starting to increase from $0.5 \%$ was significantly followed by the enzyme activity increase with enhancement of 23.81 and $31.74 \%$, respectively, for leaves and stems. Then and at $1 \%$, the activity declines gradually, whereas, the shape of the decrease curve for stems was wider in comparison with leaves, especially between the concentrations of range
$1-1.5 \%$ where there was just $11.56 \%$ of enzyme activity lost. The lowering of amylase activity can be explained by the fact that all of the substrate binding sites were filled.

Leaves $\alpha$-amylase was inhibited by all the tested ions metals, whereas stems $\alpha$-amylase was activated by $\mathrm{Co}^{2+}$ with an increase of $35 \%$ of the relative activity and it was inhibited by all other metal ions with a variable extent. It was found that calcium has a negative effect, particularly in increasing the concentration. The same process was observed with the amylase of Fenugreek seeds [45]. This effect may be due to the metal competitions and/or to the particularity of the enzyme structure. The known inhibitors $\mathrm{Zn}^{2+}$ and $\mathrm{Cu}^{2+}$ [57] induce, respectively, a different decrease in enzyme activity at $5 \mathrm{mM}$. In case of leaves and at $5 \mathrm{mM}, \mathrm{Zn}^{2+}$ leads to $87 \%$ of activity inhibition and $72 \%$ for the stems amylase. At the same concentration, the inhibition of $\mathrm{Cu}^{2+}$ was more pronounced and quasi-total. $\mathrm{Ag}^{+}$reported as a strong inhibitor at $2 \mathrm{mM}$ [58] induces a decrease of 82 and $91 \%$, respectively, of amylase from leaves and stems. Thus, among all the metal ions presented in Figure 6, $\mathrm{Co}^{2+}, \mathrm{Mg}^{2+}$, and $\mathrm{Ca}^{2+}$ seem the weaker inhibitors of the extracted amylases.

3.2. Purification of $\alpha$-Amylases. The purification profiles of $\alpha$-amylases were shown in Figure 7. The anion exchange chromatography of amylase extracted from leaves on Mono Q-Sepharose column eluted with a linear increased gradient of $\mathrm{NaCl}$ showed three peaks of activity and just two distinct peaks were revealed in case of stems.

As summarized in Table 1, amylases extracted from the two studied plant organs seemed totally different in view of their specific activities, purification fold, and yield, as well as their profiles after elution with $\mathrm{NaCl}$ as shown in Figure 7.

The purification procedure of leaves $\alpha$-amylase leads to a 11.82-fold increase in specific activity for the elution in the range of $25-149 \mathrm{mM} \mathrm{NaCl}$. It was considered as the highest fold in comparison with the two other peaks, while the higher yield of $38.33 \%$ was registered for the peak eluted in 


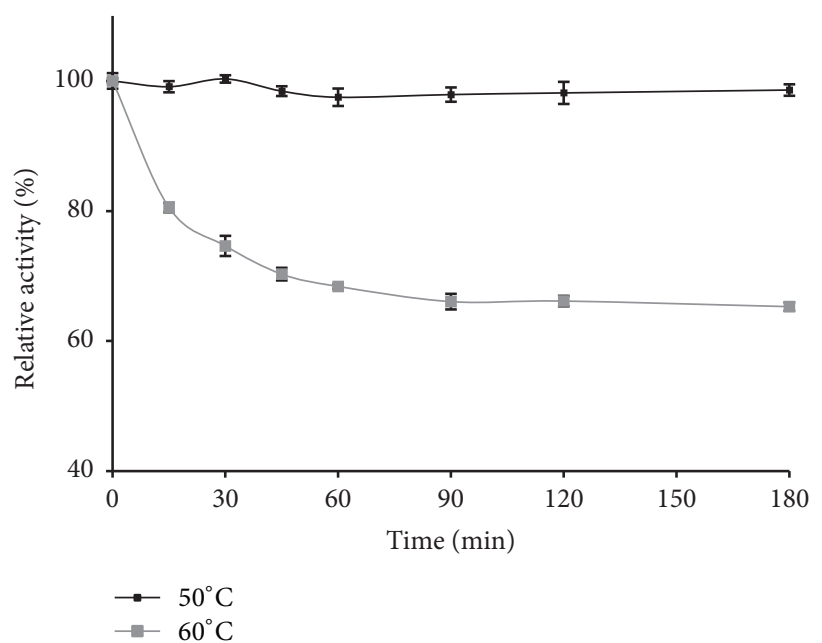

(a)

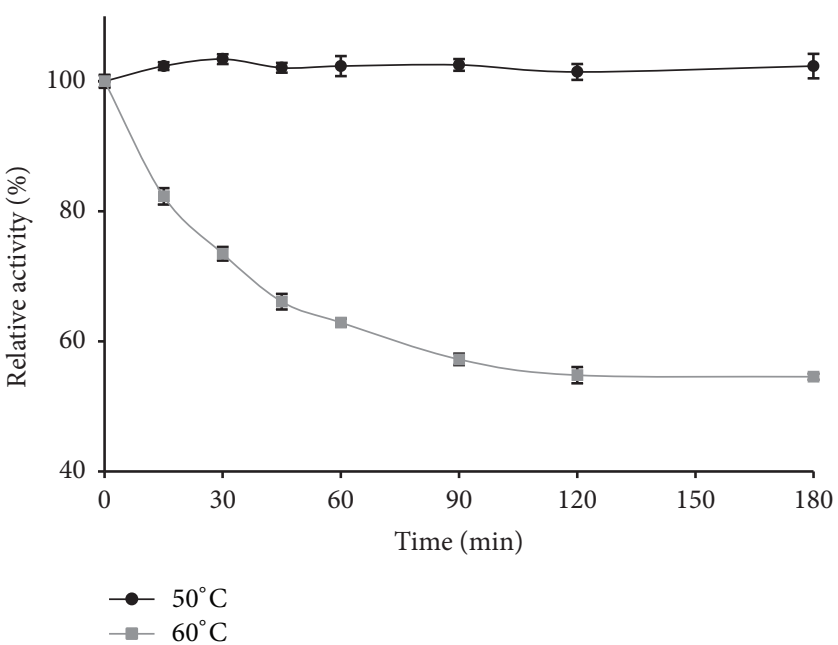

(b)

Figure 4: Thermal stability at 50 and $60^{\circ} \mathrm{C}$ of $\alpha$-amylases extracted from leaves (a) and stems (b).

TAble 1: Purification of $\alpha$-amylases extracted from leaves and stems of Pergularia tomentosa.

\begin{tabular}{|c|c|c|c|}
\hline Step & Specific activity (U/mg) & Purification (fold) & Yield (\%) \\
\hline \multicolumn{4}{|c|}{ Leaves } \\
\hline Crude extract & 0.547 & - & - \\
\hline Heat treatment & 0.558 & 1.012 & 76.905 \\
\hline \multicolumn{4}{|c|}{ Anion exchange chromatography } \\
\hline $25-149 \mathrm{mM} \mathrm{NaCl}$ & 6.463 & 11.821 & 17.19 \\
\hline $225-398 \mathrm{mM} \mathrm{NaCl}$ & 2.672 & 4.887 & 38.333 \\
\hline $402-450 \mathrm{mM} \mathrm{NaCl}$ & 3.787 & 6.927 & 23.81 \\
\hline \multicolumn{4}{|c|}{ Stems } \\
\hline Crude extract & 0.554 & - & - \\
\hline Heat treatment & 0.619 & 1.117 & 84.567 \\
\hline \multicolumn{4}{|c|}{ Anion exchange chromatography } \\
\hline $290-435 \mathrm{mM} \mathrm{NaCl}$ & 5.41 & 9.756 & 28.224 \\
\hline $620-690 \mathrm{mM} \mathrm{NaCl}$ & 6.048 & 10.924 & 27.272 \\
\hline
\end{tabular}

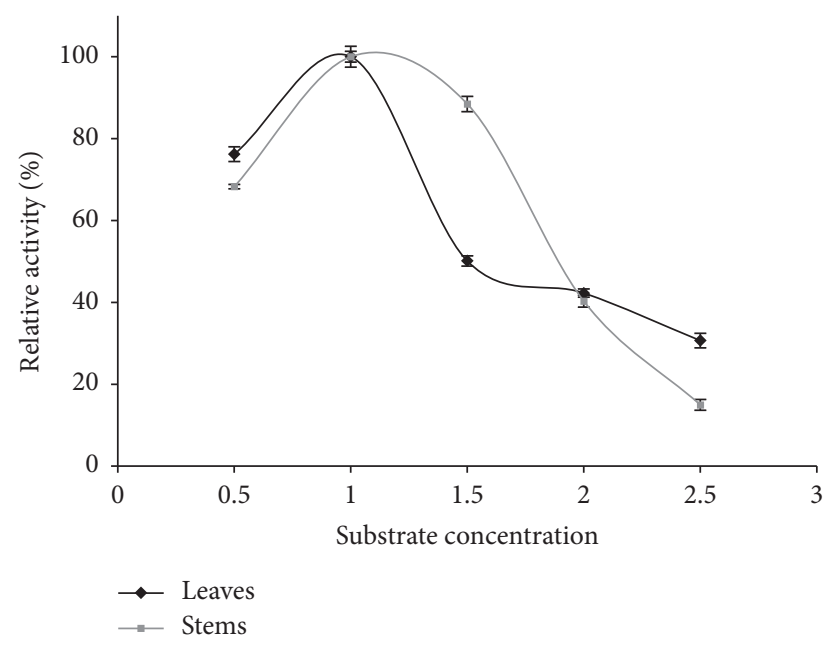

FIGURE 5: Effect of substrate concentration on the activity of $\alpha$ amylases extracted from leaves and stems.
225-398 mM NaCl. The main purification fold for stems $\alpha$ amylase was recorded for the peak eluted between 620 and $690 \mathrm{mM} \mathrm{NaCl}$ with a yield of $27.27 \%$. Nevertheless, further steps of extract concentration and purification processes such as affinity chromatography could be used to have more pure $\alpha$-amylases from Pergularia tomentosa.

3.3. Application of Stems and Leaves $\alpha$-Amylases. The above results confirm the largest activity spectra of the two amylases extracted from stems and leaves of Pergularia tomentosa at a wide range of $\mathrm{pH}$ and temperature. The revealed interesting retained activity at alkaline $\mathrm{pH}$ and moderate temperature and the exhibited amylases stability were considered as important criteria during the manufacture of commercial detergents and the degradation of starchy stains residues. The negative effect of calcium on Pergularia enzyme activity is searched to fulfil imperfect detergents suffering from oxidants sensitives and calcium-dependent $\alpha$-amylases [59]. 


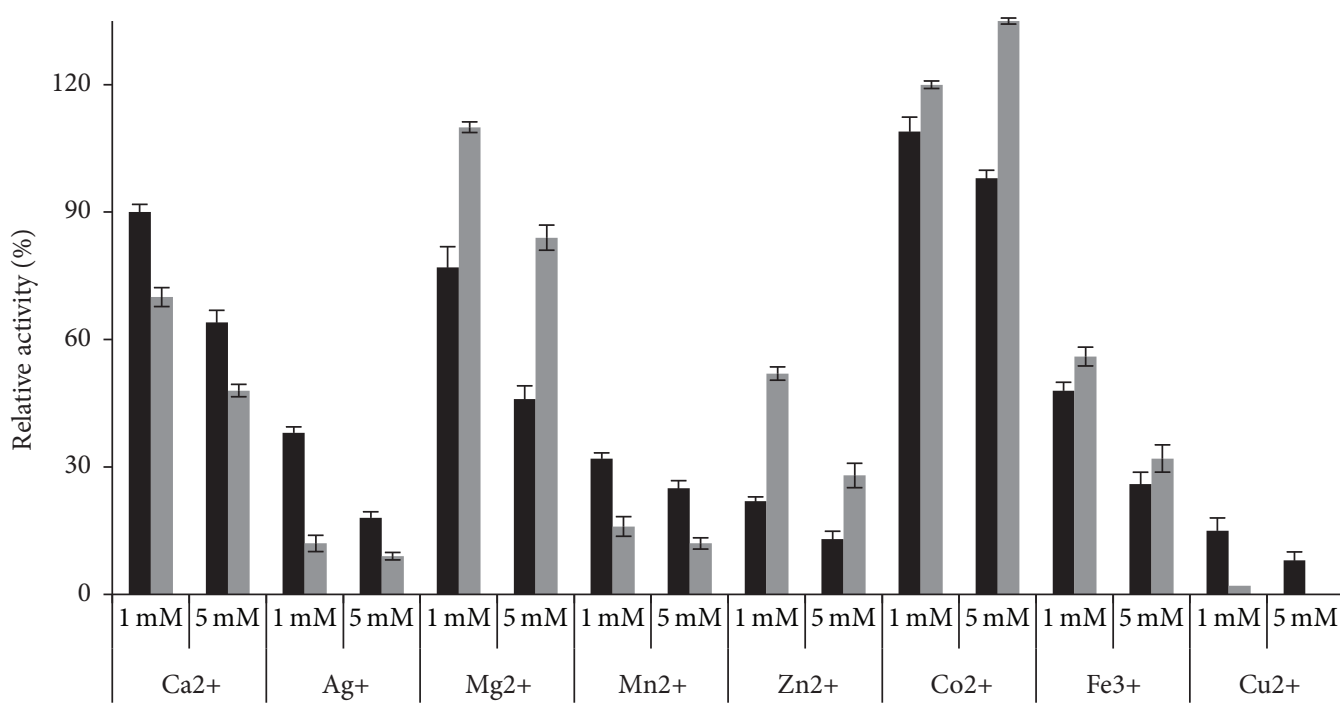

- Leaves

- Stems

Figure 6: Effect of metal ions on $\alpha$-amylase extracted from leaves and stems.

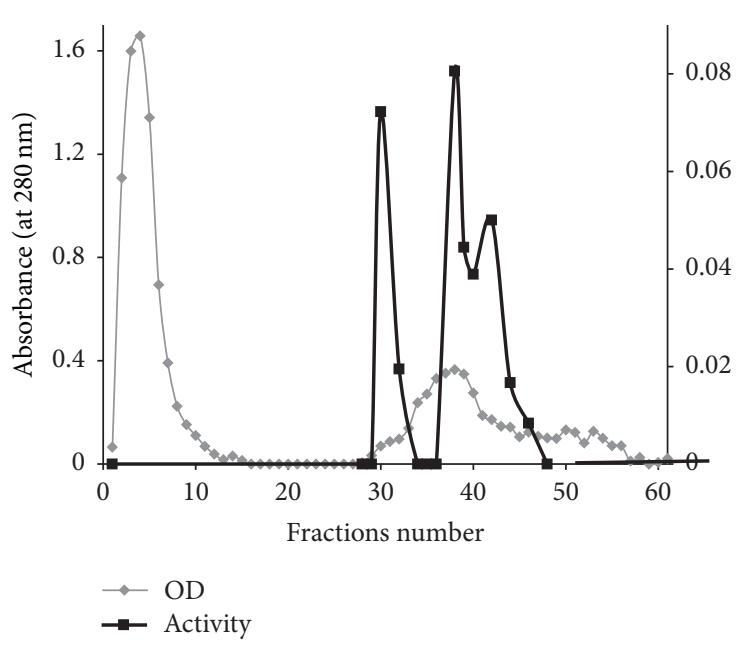

(a)

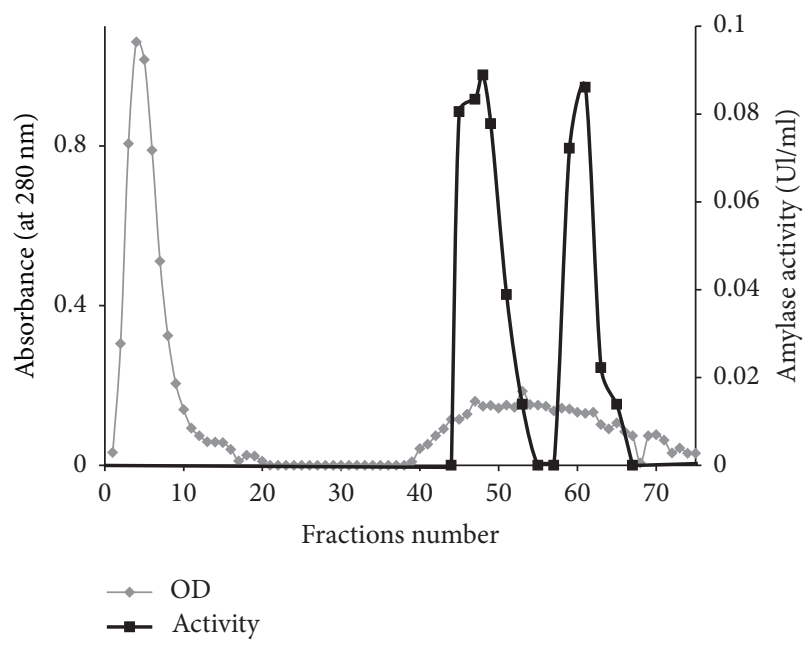

(b)

FIGURE 7: Anion exchange chromatography of $\alpha$-amylase extracted from leaves (a) and stems (b) in Mono Q-Sepharose column eluted with an increased gradient of $\mathrm{NaCl}$.

Out of the vast pool of microbial amylases enhancing whiteness effect, a similar formulation based on a wild-plant enzyme promotes widespread environmentally safe and lowcost detergents especially in rural areas [60].

However, a lucky inclusion of enzyme in the detergent formulation requires a good compatibility [61]. The data presented in Table 2 showed excellent stability and compatibility of stems and leaves $\alpha$-amylases of Pergularia tomentosa with the tested three commercial detergents.

According to the results and compared to the two other detergents, detergent $\mathrm{A}$ was considered the lowest compatible with stems and leaves amylases via the obtained residual activities, respectively, 65.22 and $80.5 \%$. Furthermore, leaves
TABLE 2: Effect of different detergents on the residual activity of extracted $\alpha$-amylases from stems and leaves of Pergularia tomentosa.

\begin{tabular}{lcc}
\hline Additive & $\begin{array}{c}\text { Residual activity of } \\
\text { stems amylase (\%) }\end{array}$ & $\begin{array}{c}\text { Residual activity of } \\
\text { leaves amylase (\%) }\end{array}$ \\
\hline Control & 100 & 100 \\
Detergent A & $65.22 \pm 0.08$ & $80.5 \pm 0.93$ \\
Detergent B & $82.63 \pm 1.14$ & $81.80 \pm 0.54$ \\
Detergent C & $87.91 \pm 1.5$ & $94.05 \pm 1.32$ \\
\hline
\end{tabular}

amylases seem to be more compatible with detergents A and $\mathrm{C}$ than stems amylase with a quasi-compatibility with 


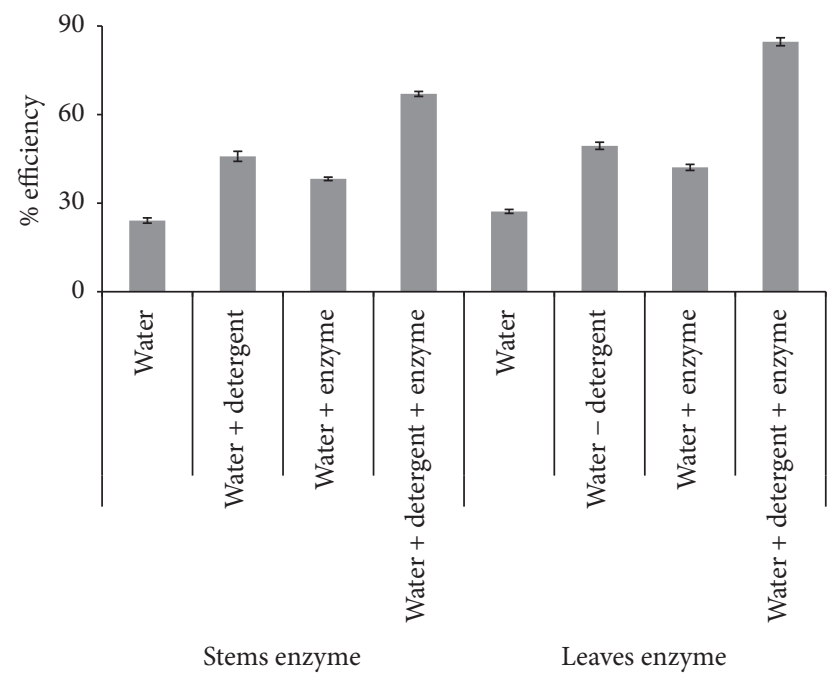

FIGURE 8: Efficiency of starch stain removal of stems and leaves $\alpha$ amylases.

the detergent $\mathrm{B}$. The detergent $\mathrm{C}$ was found to be more compatible with the two amylases, by retaining an enzyme activity of $87.91 \%$ and $94.05 \%$, respectively, for stems and leaves.

Application of $\alpha$-amylases is still very limited and a few studies reported the possibility of their implication in wash performance implying their compatibility with detergents, powder as well as liquid. Besides, the obtained results presented in Table 2 could be compared to previous researches yet they focused just on amylases extracted from fungi and bacteria $[12,13]$. In the data described above, thermal-stable $\alpha$-amylases from Pergularia tomentosa should be suggested as a competitive additive in detergent formulations, while the detergent effect on the residual activity of the discovered amylases may be attributed to the detergent composition [13].

Previous studies reported the efficiency of bacterial $\alpha$ amylase towards several raw starch sources, for instance, soluble starch, potato curry, corn, and wheat starches [14] as well tomato sauce and egg yolk [15]. Figure 8 reveals that the combination of water, detergent, and $\alpha$-amylase of stems and even leaves of Pergularia tomentosa greatly enhances the ability to remove starchy stains from cotton cloth pieces compared to the mere use of detergent or $\alpha$-amylase. The revealed increase of washing efficiency by the supplement of amylases to detergent was in accordance with other studies $[14,47]$. In fact, this combination was significantly improved when leaves $\alpha$-amylase was added with an increase of $35.24 \%$ and $42.56 \%$, respectively, with the simple enzyme wash and with the detergent wash.

The two Pergularia tomentosa $\alpha$-amylases could be integrated in industrial sectors as catalysts of stains removal and incorporated in different formulations of detergents. It could solve the problems of human skin sensitivity and side effects of the detergents residues evacuated in the environment by decreasing the amount of industrial components like surfactants, bleach, and cobuilders through the challenge of natural $\alpha$-amylases. The reputable thermal stability of
Pergularia amylases minimising the risk of contamination and the diffusion rate warrants further investigation for further industrial and biotechnological applications with a low-cost of external cooling [62].

\section{Conclusion}

The described work in this paper was attempted to characterize and purify plant $\alpha$-amylases which could be exploited in several fields like the hydrolysis of oil-field drilling fluids and the paper industry. The study of biochemical characteristics of amylases identified from Pergularia tomentosa showed a promising range of $\mathrm{pH}$ stability and an interesting thermal stability especially at $50^{\circ} \mathrm{C}$ without requirement of calcium. The simple and cheap extraction procedure of the new stems and leaves $\alpha$-amylases as well as the interesting purification fold and yields raises the great potential of our studied plant in starch stain removal as a source of biological active substances. By immobilization procedure, the amylases properties may be also improved to be implied in successful and modern biotechnology sectors.

\section{Conflicts of Interest}

The authors declare that they have no conflicts of interest.

\section{Acknowledgments}

This work was supported by the Tunisian Ministry of Research and Higher Education. The authors gratefully acknowledge the support of Professor Mohamed Chaieb, the Head of the Laboratory of Plant Biodiversity and Dynamics of Ecosystems in Arid Environment of Sfax Faculty of Sciences.

\section{References}

[1] S. B. Mabrouk, N. Aghajari, M. B. Ali et al., "Enhancement of the thermostability of the maltogenic amylase MAUS149 by Gly312Ala and Lys436Arg substitutions," Bioresource Technology, vol. 102, no. 2, pp. 1740-1746, 2011.

[2] J. Malabendu, M. Chiranjit, S. Samanta et al., "Salt-independent thermophilic $\alpha$-amylase from Bacillus megaterium VUMB109: An efficacy testing for preparation of maltooligosaccharides," Industrial Crops and Products, vol. 41, no. 1, pp. 386-391, 2013.

[3] J. S. Baek, H. Y. Kim, S. S. Yoo et al., "Synthesis of acarbose transfer products by Bacillus stearothermophilus maltogenic amylase with simmondsin," Industrial Crops and Products, vol. 12, no. 3, pp. 173-182, 2000.

[4] J.-W. Yoon, E.-J. Jeon, I.-H. Jung et al., "Maltosyl-erythritol, a major transglycosylation product of erythritol by bacillus stearothermophilus maltogenic amylase," Bioscience, Biotechnology, and Biochemistry, vol. 67, no. 3, pp. 525-531, 2003.

[5] R. Singh, V. Kumar, and V. Kapoor, "Partial purification and characterization of a heat stable $\alpha$-amylase from a thermophilic actinobacteria, Streptomyces sp. MSC702," Enzyme Research, vol. 2014, Article ID 106363, 8 pages, 2014.

[6] W. Aehle, "Development of new amylases," in Enzymes in Detergency, J. H. van Ee, O. Misset, and E. J. Baas, Eds., pp. 213229, Marcel Dekker, Inc., New York, NY, USA, 1997. 
[7] S. Ramachandran, A. K. Patel, K. M. Nampoothiri et al., "Coconut oil cake-a potential raw material for the production of $\alpha$-amylase," Bioresource Technology, vol. 93, no. 2, pp. 169-174, 2004.

[8] S. Mitidieri, A. H. S. Martinelli, A. Schrank, and M. H. Vainstein, "Enzymatic detergent formulation containing amylase from Aspergillus niger: a comparative study with commercial detergent formulations," Bioresource Technology, vol. 97, no. 10, pp. 1217-1224, 2006.

[9] S. Alva, J. Anupama, J. Savla et al., "Production and characterization of fungal amylase enzyme isolated from Aspergillus sp. JGI 12 in solid state culture," African Journal of Biotechnology, vol. 6, no. 5, pp. 576-581, 2007.

[10] M. B. Rao, A. M. Tanksale, M. S. Ghatge, and V. V. Deshpande, "Molecular and biotechnological aspects of microbial proteases," Microbiology and Molecular Biology Reviews, vol. 62, no. 3, pp. 597-635, 1998.

[11] N. Hmidet, N. El-Hadj Ali, A. Haddar, S. Kanoun, S.-K. Alya, and M. Nasri, "Alkaline proteases and thermostable $\alpha$-amylase co-produced by Bacillus licheniformis NH1: characterization and potential application as detergent additive," Biochemical Engineering Journal, vol. 47, no. 1-3, pp. 71-79, 2009.

[12] R. Roohi, M. Kuddus, and S. Saima, "Cold-active detergentstable extracellular $\alpha$-amylase from Bacillus cereus GA6: biochemical characteristics and its perspectives in laundry detergent formulation," Journal of Biochemical Technology, vol. 4, no. 4, pp. 636-644, 2013.

[13] I. Ali, A. Akbar, M. Anwar, S. Prasongsuk, P. Lotrakul, and H. Punnapayak, "Purification and characterization of a polyextremophilic $\alpha$-Amylase from an obligate halophilic Aspergillus penicillioides isolate and its potential for souse with detergents," BioMed Research International, vol. 2015, Article ID 245649, 8 pages, 2015.

[14] A. A. Simair, A. S. Qureshi, I. Khushk et al., "Production and partial characterization of $\alpha$-amylase enzyme from Bacillus sp. BCC 01-50 and potential applications," BioMed Research International, vol. 2017, Article ID 9173040, 9 pages, 2017.

[15] P. Dahiya and B. Rathi, "Characterization and application of alkaline $\alpha$-amylase from Bacillus licheniformis MTCC1483 as a detergent additive," International Food Research Journal, vol. 22, no. 3, pp. 1293-1297, 2015.

[16] N. Jaiswal and O. Prakash, "Immobilization of soybean $\alpha$ amylase on gelatin and its application as a detergent additive," Asian Journal of Biochemistry, vol. 6, no. 4, pp. 337-346, 2011

[17] M. J. Klang, P. Talamond, N. Djidimbele, F. Taveaand, and R. Ndjouenkeu, "Partial purification and characterization of a-amylases from Abrus precatorius, Burnatia enneandra and Cadaba farinose," Journal of Enzyme Research, vol. 5, no. 1, pp. 66-71, 2014.

[18] G. K. Sarker, S. Hasan, F. Nikkon et al., "Purification, characterization, and biochemical properties of $\alpha$-amylase from potato," Journal of the Korean Society for Applied Biological Chemistry, vol. 53, no. 1, pp. 8-14, 2010.

[19] W. Witt and J. J. Sauter, "Purification and characterization of $\alpha$ amylase from poplar leaves," Phytochemistry, vol. 41, no. 2, pp. 365-372, 1996.

[20] M. E. M. El Nour and S. O. Yagoub, "Partial purification and characterization of $\alpha$ and $\beta$-amylases isolated from sorghum bicolor cv. (feterita) malt," Journal of Applied Sciences, vol. 10, no. 13, pp. 1314-1319, 2010.

[21] O. Prakash and N. Jaiswal, "Immobilization of a thermostable $\alpha$-amylase on agarose and agar matrices and its application in starch stain removal," World Applied Sciences Journal, vol. 13, no. 3, pp. 572-577, 2011.

[22] M. Ernst and G. Bufler, "Stems of Allium cepa L. contain starch," New Phytologist, vol. 128, no. 3, pp. 403-406, 1994.

[23] N. Ben Halima, M. Borchani, I. Fendri et al., "Optimised amylases extraction from oat seeds and its impact on bread properties," International Journal of Biological Macromolecules, vol. 72, pp. 1213-1221, 2015.

[24] M. J. van der Maarel, B. van der Veen, J. C. Uitdehaag, H. Leemhuis, and L. Dijkhuizen, "Properties and applications of starch-converting enzymes of the $\alpha$-amylase family," Journal of Biotechnology, vol. 94, no. 2, pp. 137-155, 2002.

[25] S. A. Trejo, L. M. I. López, C. V. Cimino, N. O. Caffini, and C. L. Natalucci, "Purification and characterization of a new plant endopeptidase isolated from latex of Asclepias fruticosa L. (Asclepiadaceae)," The Protein Journal, vol. 20, no. 6, pp. 469$477,2001$.

[26] O. A. Oseni and M. M. Ekperigin, "Partial characterization of proteolytic and milk clotting enzymes in sodom apple calotropis procera (Ait.) R.Br. (asclepiadaceae) plant," American Journal of Biochemistry and Molecular Biology, vol. 3, no. 2, pp. 256-263, 2013.

[27] H. V. Shivaprasad, M. Riyaz, R. Venkatesh Kumar et al., "Cysteine proteases from the Asclepiadaceae plants latex exhibited thrombin and plasmin like activities," Journal of Thrombosis and Thrombolysis, vol. 28, no. 3, pp. 304-308, 2009.

[28] I. Lahmar, D. Manova, and L. Yotova, "Enzymes screening from crude extract of Pergularia tomentosa L," Annuaire de l'Université de Sofia "St. Kliment Ohridski" Faculte de Biologie, vol. 100, no. 4, pp. 184-190, 2015.

[29] I. Lahmar and Y. Lubov, "Investigation of different enzyme activities from Pergularia tomentosa L. and Ecballium elaterium L," Journal of Chemical Technology and Metallurgy, vol. 51, no. 3, pp. 263-270, 2016.

[30] I. Lahmar, G. Radeva, D. Marinkova et al., "Immobilization and topochemical mechanism of a new $\beta$-amylase extracted from Pergularia tomentosa," Process Biochemistry, vol. 16, pp. 386391, 2017.

[31] I. Lahmar, H. Belghith, F. Ben Abdallah, and K. Belghith, "Nutritional composition and phytochemical, antioxidative, and antifungal activities of Pergularia tomentosa L," BioMed Research International, vol. 2017, Article ID 6903817, 9 pages, 2017.

[32] R. Yakubu, F. M. Jibril, A. Lukman, and F. Sheikh, “Trends for antioxidant power of phytochemicals from Pergularia tomentosa L. (Asclepiadacea) whole plant," Scholars Academic Journal of Pharmacy, vol. 4, no. 2, pp. 74-80, 2015.

[33] A. M. Abou-Zeid, A. D. Altalhi, and R. I. Abd El-Fattah, "Fungal control of pathogenic fungi isolated from some wild plants in Taif governorate, Saudi Arabia," Malasyian Journal of Microbiology, vol. 4, no. 1, pp. 30-39, 2008.

[34] S. A. H. Al-Jabri, Chemical and bio-analytical studies on Pergulariatomentosa and species from the Mentha genus [Ph.D. thesis], University of Leicester, 2013.

[35] S. A. Shinkafi, "Antidermatophytic activities of column chromatographic fractions and toxicity studies of Pergularia tomentosaL. and Mitracarpus scaber Zucc. used in the treatment of dermatophytoses," Advancement in Medicinal Plant Research, vol. 2, no. 1, pp. 7-15, 2014.

[36] H. I. Hussein, D. Al-Rajhy, F. I. E. Shahawi, and S. M. Hashem, "Molluscicidal activity of pergularia tomentosa (1.), methomyl 
and methiocarb, against land snails," International Journal of Pest Management, vol. 45, no. 3, pp. 211-213, 1999.

[37] S. H. M. Bekheet, F. F. Abdel-Motaal, and U. A. Mahalel, "Antifungal effects of Ficus sycomorus and Pergularia tomentosa aqueous extracts on some organs in Bufo regularis treated with Aspergillus niger," Tissue \& Cell, vol. 43, no. 6, pp. 398-404, 2011.

[38] S. M. Dangoggo, U. Z. Faruq, and L. G. Hassan, "Preliminary phtyochemical analysis and antibacterial activity of Pergularia tomentosa," Sokoto Journal of Veterinary Sciences, vol. 4, no. 2, pp. 8-11, 2002.

[39] S. Piacente, M. Masullo, N. De Nève et al., "Cardenolides from Pergularia tomentosa display cytotoxic activity resulting from their potent inhibition of $\mathrm{Na}+\mathrm{K}+$-ATPase," Journal of Natural Products, vol. 72, no. 6, pp. 1087-1091, 2009.

[40] P. W. C. Green, N. C. Veitch, P. C. Stevenson, and M. S. J. Simmonds, "Cardenolides from Gomphocarpus sinaicus and Pergularia tomentosa (Apocynaceae: Asclepiadoideae) deter the feeding of Spodoptera littoralis," Arthropod-Plant Interactions, vol. 5, no. 3, pp. 219-225, 2011.

[41] V. Jagannathan, K. Singh, and M. Damodaran, "Carbohydrate metabolism in citric acid fermentation. 4. Purification and properties of aldolase from Aspergillus niger," Biochemical Journal, vol. 63, no. 1, pp. 94-105, 1956.

[42] M. M. Bradford, "A rapid and sensitive method for the quantitation of microgram quantities of protein utilizing the principle of protein dye binding," Analytical Biochemistry, vol. 72, no. 1-2, pp. 248-254, 1976.

[43] G. L. Miller, "Use of dinitrosalicylic acid reagent for determination of reducing sugar," Analytical Chemistry, vol. 31, no. 3, pp. 426-428, 1959.

[44] M. Asgher, M. J. Asad, S. U. Rahman, and R. L. Legge, "A thermostable $\alpha$-amylase from a moderately thermophilic Bacillus subtilis strain for starch processing," Journal of Food Engineering, vol. 79, no. 3, pp. 950-955, 2007.

[45] B. Khemakhem, I. Fendri, I. Dahech, K. Belghuith, R. Kammoun, and H. Mejdoub, "Purification and characterization of a maltogenic amylase from Fenugreek (Trigonella foenum graecum) seeds using the Box Benkhen Design (BBD)," Industrial Crops and Products, vol. 43, no. 1, pp. 334-339, 2013.

[46] A. S. Qureshi, I. Khushk, C. H. Ali, Y. Chisti, A. Ahmad, and H. Majeed, "Coproduction of protease and amylase by thermophilic Bacillus sp. BBXS-2 using open solid-state fermentation of lignocellulosic biomass," Biocatalysis and Agricultural Biotechnology, vol. 8, pp. 146-151, 2016.

[47] R. J. Shukla and S. P. Singh, "Characteristics and thermodynamics of $\alpha$-amylase from thermophilic actinobacterium, Laceyella sacchari TSI-2," Process Biochemistry, vol. 50, no. 12, pp. 21282136, 2015.

[48] A. Kumari and A. M. Kayastha, "Immobilization of soybean (Glycine max) $\alpha$-amylase onto Chitosan and Amberlite MB-150 beads: Optimization and characterization," Journal of Molecular Catalysis B: Enzymatic, vol. 69, no. 1-2, pp. 8-14, 2011.

[49] M. Ben Elarbi, H. Khemiri, T. Jridi, and J. Ben Hamida, "Purification and characterization of $\alpha$-amylase from safflower (Carthamus tinctorius L.) germinating seeds," Comptes Rendus Biologies, vol. 332, no. 5, pp. 426-432, 2009.

[50] M. A. K. Azad, J.-H. Bae, J.-S. Kim et al., "Isolation and characterization of a novel thermostable $\alpha$-amylase from Korean pine seeds," New Biotechnology, vol. 26, no. 3-4, pp. 143-149, 2009.

[51] S. A. Fincan and B. Enez, "Production, purification, and characterization of thermostable a-amylase from thermophilic
Geobacillus stearothermophilus," Starch - Stärke, vol. 66, no. 1-2, pp. 182-189, 2014.

[52] L. Haifeng, C. Zhenming, W. Xiaohong, and M. Chunling, "Amylase production by the marine yeast Aureobasidium pullulans N13D," Journal of Ocean University of China, vol. 6, no. 1, pp. 60-65, 2007.

[53] A. A. Hasper, E. Dekkers, M. Van Mil, P. J. I. Van de Vondervoort, and L. H. De Graaff, "EglC, a new endoglucanase from Aspergillus niger with major activity towards xyloglucan," Applied and Environmental Microbiology, vol. 68, no. 4, pp. 1556-1560, 2002.

[54] R. Scriban, "Biotechnologies," in Techniques et DocumentationLavoisier, pp. 149-157, 5th edition, 1999.

[55] A. Ghasemi, S. Ghafourian, S. Vafaei et al., "Cloning, Expression, and Purification of Hyperthermophile $\alpha$-Amylase from Pyrococcus woesei," Osong Public Health and Research Perspectives, vol. 6, no. 6, pp. 336-340, 2015.

[56] H. El Abed, M. Chakroun, I. Fendri et al., "Extraction optimization and in vitro and in vivo anti-postprandial hyperglycemia effects of inhibitor from Phoenix dactylifera L. parthenocarpic fruit," Biomedicine \& Pharmacotherapy, vol. 88, pp. 835-843, 2017.

[57] M. Ennouri, B. Khemakhem, H. B. Hassen, I. Ammar, K. Belghith, and H. Atti, "Purification and characterization of an amylase from Opuntia ficus-indica seeds," Journal of the Science of Food and Agriculture, vol. 93, no. 1, pp. 61-66, 2013.

[58] A. P. Ranwala and W. B. Miller, "Purification and characterization of an endoamylase from tulip (Tulipa gesneriana) bulbs," Physiologia Plantarum, vol. 109, no. 4, pp. 388-395, 2000.

[59] A. Sundarram and T. P. K. Murthy, " $\alpha$-Amylase production and applications: a review," Journal of Applied and Environmental Microbiology, vol. 2, no. 4, pp. 166-175, 2014.

[60] P. M. de Souza and P. O. Magalhães, "Application of microbial $\alpha$-amylase in industry-a review," Brazilian Journal of Microbiology, vol. 41, no. 4, pp. 850-861, 2010.

[61] A. K. Mukherjee, H. Adhikari, and S. K. Rai, "Production of alkaline protease by a thermophilic Bacillus subtilis under solidstate fermentation (SSF) condition using Imperata cylindrica grass and potato peel as low-cost medium: characterization and application of enzyme in detergent formulation," Biochemical Engineering Journal, vol. 39, no. 2, pp. 353-361, 2008.

[62] A. Roy, K. Khanra, A. Mishra, and N. Bhattacharyya, "Partial purification and characterization of amylase from a newly isolated Bacillus Megaterium strain KAN1 from fermented Rice Handia," American Journal of Current Microbiology, vol. 2, no. 1, pp. 1-5, 2014. 

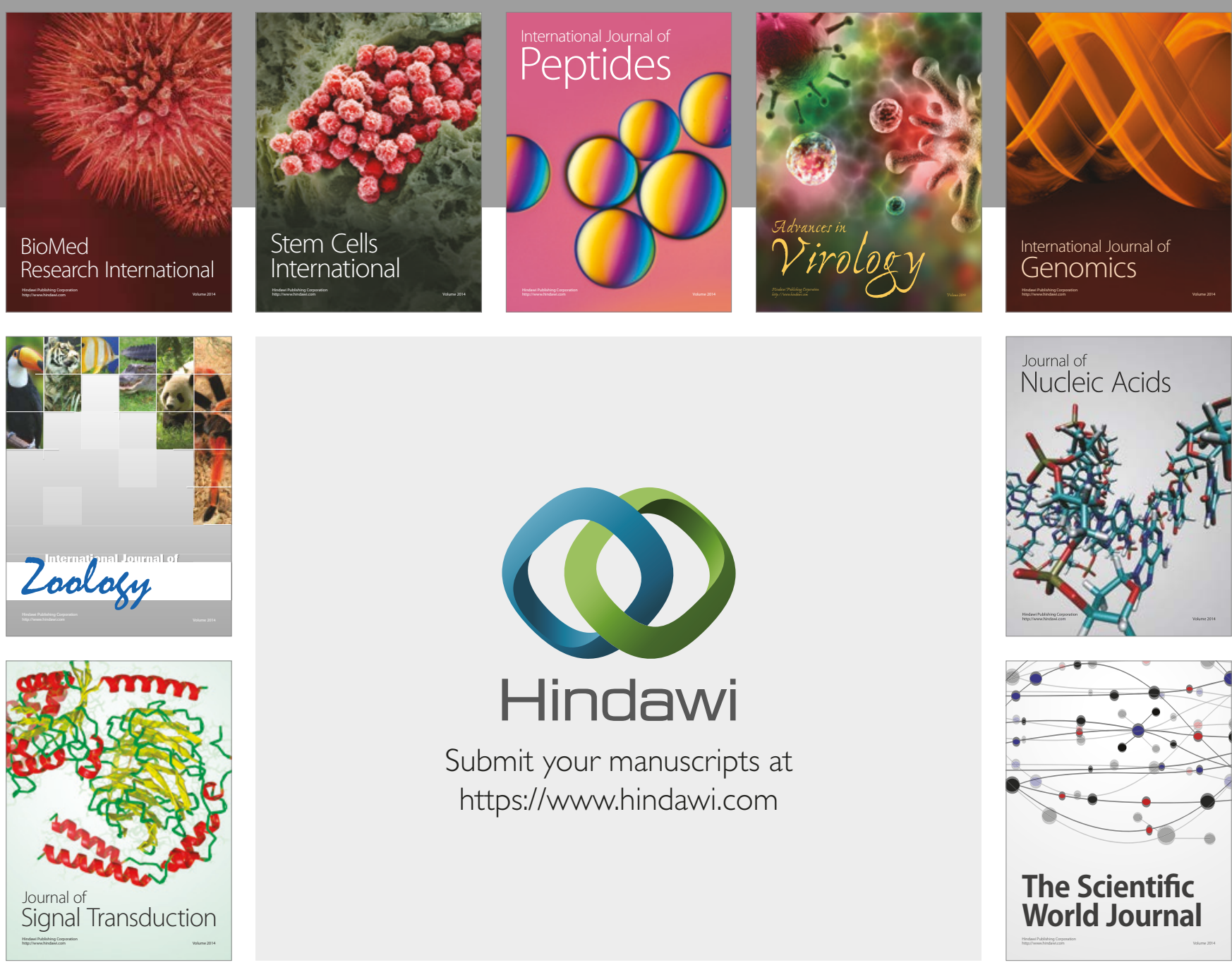

Submit your manuscripts at

https://www.hindawi.com
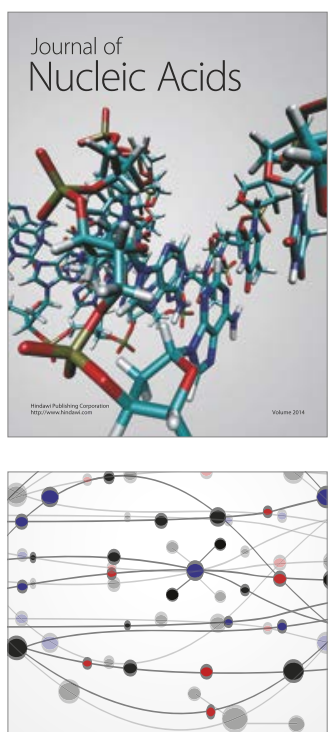

The Scientific World Journal

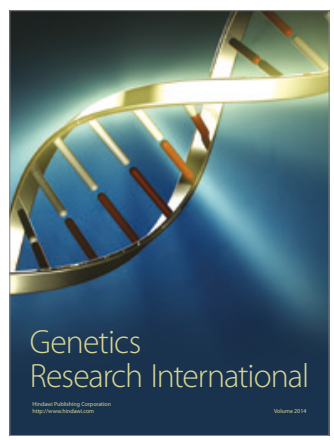

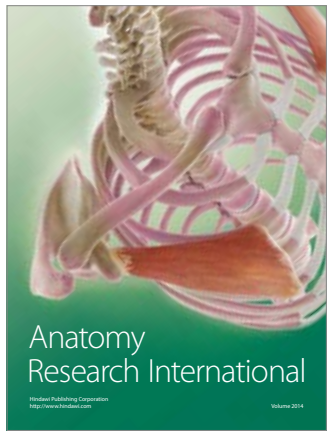

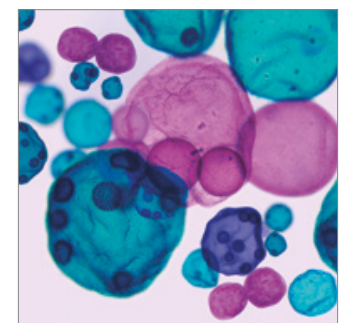

International Journal of Microbiology
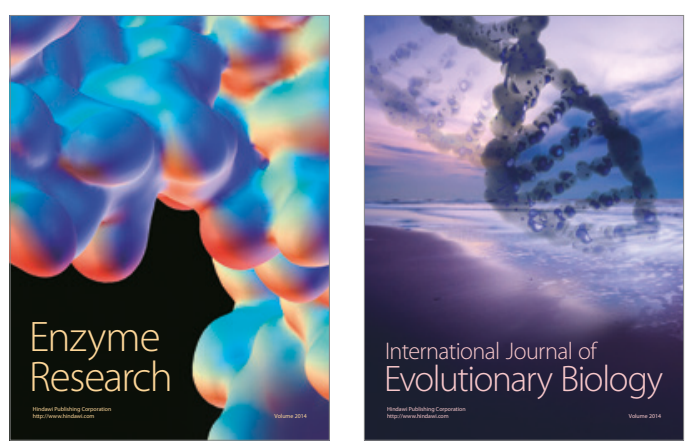
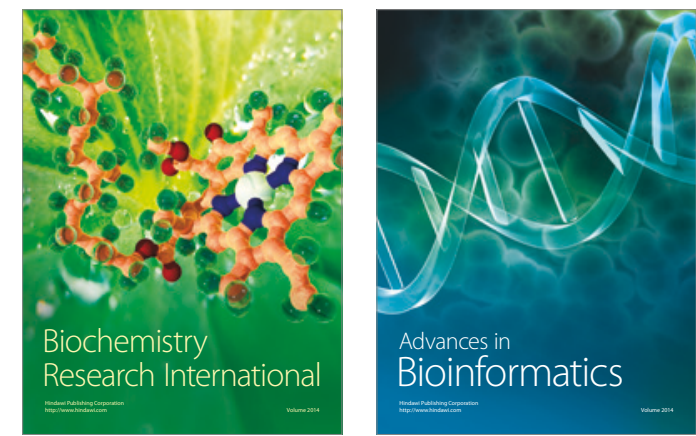

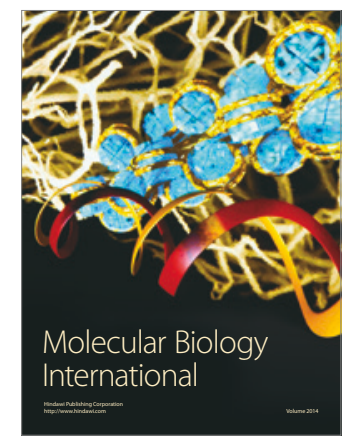

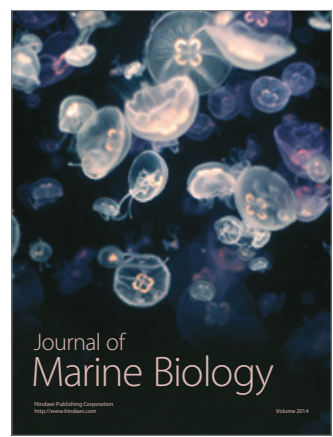

